\title{
PReS-FINAL-2204: Developing of a new scale for assessing the adherence to colchicines treatment in pediatric patients with FMF
}

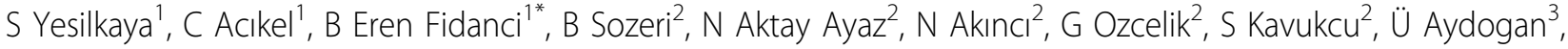

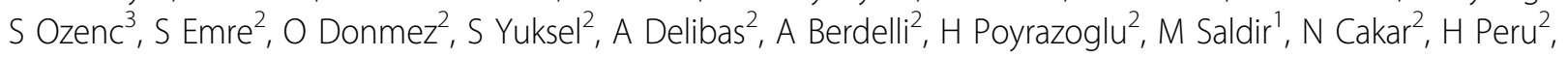 \\ S Bakkaloglu², Y Tabel ${ }^{2}$, O Sari ${ }^{1}$, A Polat ${ }^{1}$, G Basbozkurt ${ }^{1}$, E Unsal ${ }^{2}$, F Gok ${ }^{1}$, O Kasapcopur ${ }^{2}$, S Ozen ${ }^{4}$, E Demirkaya ${ }^{1}$, \\ FMF Arthritis Vasculitis and Orphan disease Research in Paediatric Rheumatology (FAVOR)
}

From 20th Pediatric Rheumatology European Society (PReS) Congress

Ljubljana, Slovenia. 25-29 September 2013

\section{Introduction}

Familial Mediterranean Fever (FMF) is a disease characterized by attacks and colchicine is the medication considered most effective in reducing the intensity and frequency of attacks. Adherence to the medication regiment is important not only to manage FMF symptoms, but also to prevent amyloidosis.

\section{Objectives}

In this study, it is aimed to develop and assess the validity and reliability of the adherence scale for colchicine treatment in pediatric FMF patients.

\section{Methods}

This study was planned as a methodological study to development of scale for assessment of adherence to treatment of pediatric patients with FMF using colchicine treatment. Pediatric patients (2-18 ages) with FMF using colchicine at least 6 months and accepted to participate in the study constitute the sample of the study. "Data collection forms about the sociodemographic and medical information (demographic, clinical and laboratory findings) of patients", "adherence scale for colchicine in pediatric FMF patients" and "Morisky Medication Adherence Scale" were used as data collection instruments. If the patient was under 7 years old, his parents filled the forms.

\section{Results}

There were 150 patients with FMF enrolled for the validation of the study. The median age of the patients was $11.11 \pm 4.02$ (min.2.74-max.17.99) and 48.7\% of them were male. The median of the attack frequency was $11,00 \pm 10,74(\min .0$-max 52$)$ and $60.7 \%$ of the participants had irregular attacks.

For internal consistency, Cronbach's alpha was 0,728 for "adherence scale for colchicine in pediatric FMF patients". Also, there was a positive and significant correlation ( $\mathrm{r}: 0.843, \mathrm{p}<0.001)$ between test and retest score. As a result it is accepted that this scale can be used for pediatric patients with FMF who use colchicine as a "reliable scale". As a "content validity" 13 experts' opinion were taken. As a "surface validity" a preliminary test was applied with 15 patients. For the "criterion validity" the correlation between this scale and Morisky medication adherence scale was evaluated and for the "structure" validity, factor analyzes and Kaiser-MeyerOlkin tests were performed. According to the results this scale was accepted as a "valid" to assessing of adherence to treatment of pediatric patients with FMF who use colchicine.

\section{Conclusion}

Based on these results, using this scale for the purpose of the assessment and follow up of adherence to treatment of pediatric patients with FMF who use colchicine is recommended.

${ }^{1}$ Gulhane Military Medical Academy, Ankara, Turkey

Full list of author information is available at the end of the article 


\section{Disclosure of interest}

None declared.

\section{Authors' details}

${ }^{1}$ Gulhane Military Medical Academy, Ankara, Turkey. ${ }^{2}$ FAVOR, Ankara, Turkey.

${ }^{3}$ GATA Family Medicine, Ankara, Turkey. ${ }^{4}$ Hacettepe University, Ankara

Turkey.

Published: 5 December 2013

doi:10.1186/1546-0096-11-S2-P194

Cite this article as: Yesilkaya et al:: PReS-FINAL-2204: Developing of a new scale for assessing the adherence to colchicines treatment in pediatric patients with FMF. Pediatric Rheumatology 2013 11(Suppl 2):

P194.

Submit your next manuscript to BioMed Central and take full advantage of:

- Convenient online submission

- Thorough peer review

- No space constraints or color figure charges

- Immediate publication on acceptance

- Inclusion in PubMed, CAS, Scopus and Google Scholar

- Research which is freely available for redistribution 